Anna Franusz

Uniwersytet Warmińsko-Mazurski w Olsztynie

\title{
PRZESŁANKI UDZIAŁU ORGANIZACJI POZARZAZDOWYCH W POSTĘPOWANIU CYWILNYM ZE SZCZEGÓLNYM UWZGLĘDNIENIEM ORGANIZACJI ZAJMUJĄCYCH SIĘ OCHRONA ŚRODOWISKA
}

\section{Wprowadzenie}

Dostrzegając potrzebę zagwarantowania organizacjom pozarządowym jak najefektywniejszej realizacji celów statutowych, ustawodawca umożliwił im uczestniczenie w postępowaniu cywilnym, co z założenia ma m.in. ułatwiać pomoc osobom fizycznym w dochodzeniu ich praw. Podstawę prawną takiego udziału stanowią art. 8 oraz art. $61-63$ k.p.c. ${ }^{1}$ Stosownie do art. 8 k.p.c. organizacje pozarządowe (w tym również zajmujące się ochroną środowiska), których działalność statutowa nie polega na prowadzeniu działalności gospodarczej, ${ }^{2}$ mogą dla ochrony praw obywateli wszcząć postępowanie oraz wziąć udział w toczącym się postępowaniu (art. 61 i 62 k.p.c.). Wszczęcie postępowania zwykle polega na wytoczeniu powództwa, odwołaniu się od decyzji właściwego organu lub na wniesieniu wniosku ${ }^{3}$ do sądu na rzecz i za zgodą osoby fizycznej. Oprócz możliwości zainicjowania np. procesu, podmioty te mogą przyłączyć się do konkretnej osoby fizycznej poprzez wstąpienie do toczącego się postępowania. Ponadto ustawodawca umożliwił organizacjom pozarządowym, które nie uczestniczą w sprawie na zasadach wskazanych powyżej, przedstawienie poglądu istotnego dla sprawy, przybierającego postać uchwały lub oświadczenia ich należycie umocowanych organów (art. 63 k.p.c.).

Ustawa z dnia 17 listopada 1964 r. Kodeks postępowania cywilnego (powoływana dalej jako k.p.c.)

Prowadzenie przez organizację działalności gospodarczej jest negatywną przesłanką udziału organizacji w postępowaniu cywilnym na zasadach określonych w art. 61-63 k.p.c.

3 Organizacje mogą żądać wszczęcia postępowania nieprocesowego, egzekucyjnego, zabezpieczającego. Por. M. Jędrzejewska, (w:) T. Ereciński, J. Gudowski, M. Jędrzejewska, Kodeks postępowania cywilnego. Komentarz. Część pierwsza. Postępowanie rozpoznawcze. Część druga postępowania zabezpieczające. Tom 1, Warszawa 2006, s. 97. 
Podkreślić należy, iż wskazane powyżej przepisy ograniczają udział organizacji pozarządowych zajmujących się ochroną środowiska do sytuacji, w których ochrony wymagają również prawa obywatela. Uczestnicząc w postępowaniu w oparciu o art. 8 k.p.c. oraz art. 61-62 k.p.c. organizacje nie mają na względzie własnego, bezpośredniego interesu, ${ }^{4}$ lecz działają one na rzecz oraz w interesie osoby fizycznej, choć - co wymaga podkreślenia - we własnym imieniu. Z tego względu uprawniony wydaje się wniosek, że interes prawny osoby fizycznej staje się niejako interesem organizacji.

Warto odnotować, iż organizacje pozarządowe (pod warunkiem, że posiadają zdolność sądową i procesową), jako klasyczne podmioty stosunków cywilnoprawnych uprawnione są, rzecz jasna, do występowania do sądu w celu ochrony, czy zabezpieczenia swoich interesów. Wówczas jednak działają one na zasadach ogólnych, pozostając tzw. rzeczywistą stroną postępowania. ${ }^{5}$ Tymczasem w analizowanej sytuacji organizacja nie występuje jako podmiot stosunku prawnego lub prawa, którego dotyczy postępowanie, lecz udziela wsparcia osobie fizycznej, będącej faktyczną stroną stosunku prawnego lub prawa. Okoliczność ta w zasadniczy sposób wpływa na problematykę stanowiącą przedmiot niniejszych rozważań, w szczególności zaś na zagadnienie legitymacji procesowej organizacji pozarządowych działających w interesie osób trzecich.

Udział organizacji pozarządowych $\mathrm{w}$ postępowaniu cywilnym na zasadach określonych $\mathrm{w}$ art. 8 k.p.c. oraz 61 i 62 k.p.c. uzależniony jest od spełnienia szeregu warunków. Przybierają one, o czym będzie mowa poniżej, postać przesłanek zarówno o formalnej (umożliwiających merytorycznie rozpoznanie sprawy), jak i materialnej (wpływających na ewentualne uwzględnienie żądań organizacji w orzeczeniu rozstrzygającym co do istoty) naturze. Pierwsza grupa elementów o charakterze podmiotowym, niezbędnych do występowania $\mathrm{w}$ postępowaniu cywilnym w charakterze strony lub uczestnika zaliczana jest do tzw. pozytywnych przesłanek procesowych i pozostaje w związku z powinnością posiadania zdolności sądowej i procesowej. Odrębną grupę zagadnień stanowią kwestie składające się na istotę legitymacji procesowej organizacji pozarządowych. Należy do nich zaliczyć: stosowne relacje między charakterem sprawy a rodzajem działalności statutowej, swoisty interes prawny organizacji oraz zgodę osoby fizycznej na udział organizacji w postępowaniu cywilnym.

$4 \quad$ K. Piasecki, Postępowanie sporne rozpoznawcze w sprawach cywilnych, Warszawa 2011, s. 230.

5 W. Broniewicz, A. Marciniak, I. Kunicki, Postępowanie cywilne w zarysie, Warszawa 2014, s. 79. 
Przesłanki udziału organizacji pozarządowych w postępowaniu cywilnym...

\section{Zdolność sądowa i zdolność procesowa organizacji pozarządowych}

Udział organizacji pozarządowej w postępowaniu cywilnym w charakterze uczestnika oraz możliwość dokonywania przez jej organy czynności procesowych ustawodawca uzależnił od posiadania przez tę organizację zdolności sądowej i zdolności procesowej. Atrybuty te są immanentnie sprzężone ze zdolnością prawną oraz zdolnością do czynności prawnych, zaś kwestię zdolności sądowej i procesowej należy rozpatrywać przez pryzmat art. $64 \S 1$ oraz $65 \S 1$ k.p.c. Sygnalizowane powyżej uregulowania (znowelizowane w 2012 r. ${ }^{6}$ ) zawierają katalog podmiotów odznaczających się tak zdolnością sądową, jak i procesową. W odniesieniu do organizacji pozarządowej podkreślić należy, iż powyższe atrybuty przysługują jej o tyle, o ile stanowi ona osobę prawną lub jednostkę organizacyjną niebędącą osobą prawną, której ustawa przyznaje zdolność prawną. Organizacje pozarządowe przybierają zwykle postać jednej ze wskazanych powyżej form organizacyjnych, stąd teoretycznie każda z nich może być działającym, tj. dokonującym czynności procesowych, uczestnikiem postępowania cywilnego.

Jak wspomniano, zdolność sądowa i procesowa należą do pozytywnych przesłanek procesowych i są one niezbędne do prawidłowego wszczęcia i zakończenia postępowania cywilnego. ${ }^{7}$ Podkreślić należy, że jeżeli w chwili wniesienia pozwu organizacja pozarządowa działająca w procesie na cudzą rzecz nie będzie posiadała zdolności sądowej (w konsekwencji zaś zdolności procesowej), wówczas po bezskutecznym upływie terminu na uzupełnienie braku, sąd postanowieniem odrzuci pozew (199 § 1 i $§ 2$ k.p.c.).

W wypadku następczej utraty zdolności sądowej i procesowej (np. wskutek skreślenia organizacji z rejestru osób prawnych), sąd obligatoryjnie zawiesi postępowanie do czasu uzupełnienia braku. W razie stwierdzenia, iż następca prawny strony nie istnieje, postępowanie należy umorzyć wydając odpowiednie postanowienie (art. $182 \S$ k.p.c. w zW. z art. $174 \S 1$ pkt. 1 k.p.c.). W opisywanych przypadkach zachodzi niemożność merytorycznego rozpoznania sprawy, zaś kontynuowanie postępowania wbrew obowiązkowi jego zawieszenia, umorzenia lub odrzucenia pozwu stanowić będzie przykład najpoważniejszego naruszenia przepisów procedury, skutkującego nieważnością postępowania (art. 379 pkt. 2 k.p.c.). Jeśli utrata zdolności sądowej przez organizację nastąpiła po przystąpieniu do postępowania osoby, na rzecz któ-

$6 \quad$ Stosownie do k.p.c. w brzmieniu sprzed nowelizacji, która weszła w życie 3 maja 2012 r., oprócz osób fizycznych i osób prawnych i jednostek organizacyjnych niebędących osobami prawnymi, którym ustawa przyznaje zdolność prawną, zdolność sądową (art. 64 § 2) oraz zdolność procesową (65 § 1) posiadały również organizacje społeczne uprawnione do udziału wedle przepisów prawa, choćby nie posiadały osobowości prawnej. Ujęcie organizacji w ramach powyższych przepisów uznano za superfluum ustawowe, gdyż podmioty te zasadniczo stanowią osoby prawne lub jednostki organizacyjne nieposiadające osobowości prawnej.

7

M. Jędrzejewska, (w:) T. Ereciński (red.), Kodeks..., op. cit., s. 484; eadem, (w:) T. Resich (red.), System prawa procesowego cywilnego, Tom II, Wrocław, Warszawa, Kraków, Gdańsk, Łódź 1987, s. 56 i n.; H. Pietrzkowski, Metodyka pracy sędziego w sprawach cywilnych, Warszawa 2009, s. 98-103. 
rej wytoczono powództwo (mają tu wówczas odpowiednio zastosowanie przepisy o współuczestnictwie jednolitym) ${ }^{8}$ zgodnie z poglądami przedstawicieli doktryny sąd powinien zawiesić postępowanie względem obydwu powodów, bowiem istota współuczestnictwa jednolitego polega na tym, iż wyrok niepodzielnie będzie dotyczył wszystkich współuczestników. ${ }^{9}$

Sytuacja kształtuje się inaczej w przypadku przystąpienia organizacji pozarządowej do jednej ze stron procesu, gdyż wówczas, stosownie do art. $62 \S 2$ k.p.c., odpowiednio stosuje się przepisy o interwencji ubocznej. ${ }^{10}$ Zasadnicza różnica między przystąpieniem do sporu interwenienta ubocznego a wstąpieniem organizacji pozarządowej wyraża się w motywach, leżących u podstaw udziału każdego z tych podmiotów w procesie. Interwenient - w swym postępowaniu - kieruje się własnym interesem prawnym, podczas gdy celem organizacji jest chęć niesienia pomocy obywatelom. W literaturze przedmiotu nie budzi wątpliwości pogląd, że interwenient uboczny, podobnie jak strony postępowania, musi posiadać zdolność sądową i procesową. ${ }^{11}$ Ujawnienie jakichkolwiek braków w zakresie zdolności sądowej interwenienta przystępującego do postępowania nie skutkuje, rzecz jasna, odrzuceniem pozwu, lecz odrzuceniem interwencji. ${ }^{12}$ Analiza stanowisk prezentowanych w doktrynie uzasadnia konstatację, że kwestia obowiązku zawieszenia postępowania w przypadku utraty w toku postępowania zdolności sądowej interwenienta ubocznego niesamoistnego nie doczekała się jednomyślnej oceny. Część autorów stoi na stanowisku, iż powyższa okoliczność nie stanowi podstawy do wydania postanowienia o zawieszeniu postępowania. ${ }^{13}$ Odmienny pogląd prezentuje $\mathrm{SN}^{14}$ i niektórzy przedstawiciele doktryny ${ }^{15}$ uznając, że niesamoistny charakter interwencji również wywołuje potrzebę zawieszenia postępowania w przypadku śmierci interwenienta. Wydaje się, że wola zapewnienia ochrony interesu prawnego interwenienta i w konsekwencji uniknięcie sytuacji, w której ów interes mógłby ulec zagrożeniu na skutek utraty przez interwenienta zdolności sądowej lub procesowej, stanowi koronny argument SN przemawiający za tezą o niezbędności zawieszenia postępowania w stosunku do interwenienta niesamoistnego. Podejmując próbę ustosunkowania się do

W opisywanym przypadku zastosowanie mają odpowiednio przepisy dotyczące przystąpienia do sprawy strony, na rzecz której powództwo zostało wytoczone przez prokuratora, do której to sytuacji z kolei odpowiednie zastosowanie znajdą przepisy o współuczestnictwie jednolitym (art. $56 \S 1$ k.p.c. w zw. z art. 62 § 1 k.p.c.). A. Jakubecki, (w:) H. Dolecki (red.), Kodeks postępowania cywilnego. Komentarz. Tom I. Artykuły 1-366, LEX nr 147118; M. Jędrzejewska, (w:) T. Ereciński (red.), Kodeks..., op. cit., s. 388. Podobnie: SN z dnia 10 października 1964 r., III CO 53/64, OSPiKA 1968, Nr 2, poz. 29; OSNC 1965, Nr 6, poz. 94. W opisywanym przypadku zastosowanie mają przepisy o interwencji ubocznej z wyjątkiem interwencji samoistnej, do której nie mają odpowiedniego zastosowania przepisy o współuczestnictwie jednolitym. W. Broniewicz, Zdolność sądowa w postępowaniu cywilnym, „Nowe Prawo” 1965, nr 5, s. 577; P. Telenga, (w:) A. Jakubecki (red.), Komentarz aktualizowany do ustawy z dnia 17 listopada 1964 r. Kodeks postępowania cywilnego, LEX Nr 166029. Por. również: postanowienie SN z dnia 18 grudnia 1997 r., III CKN 473/97, OSNC 1998, Nr 7-8, poz. 117, OSP 1998, Nr 9, poz. 163. Tak: P. Telenga, (w:) A. Jakubecki (red.), Komentarz..., op. cit., LEX Nr 166042. 
tych dwóch przeciwstawnych zapatrywań stwierdzić należy, że mając na względzie istotę udziału organizacji pozarządowej w postępowaniu, pogląd wyrażony przez SN wydaje się nie mieć zastosowania w interesującej nas sytuacji. W przeciwieństwie bowiem do interwenienta ubocznego, udział organizacji pozarządowej nie wynika z potrzeby ochrony własnego, bezpośredniego interesu prawnego (majątkowego lub niemajątkowego).

\section{Legitymacja procesowa organizacji pozarządowej w sprawach o ochronę środowiska}

Zasadniczo nie budzi wątpliwości teza, iż posiadanie legitymacji procesowej przez strony postępowania stanowi jedną $\mathrm{z}$ materialnoprawnych przesłanek uwzględnienia powództwa. ${ }^{16}$ A contrario, brak wspomnianej legitymacji uzasadnia jego oddalenie. ${ }^{17}$ Powyższa zależność wynika z istoty legitymacji procesowej, określanej zwykle jako wynikające z prawa materialnego uprawnienia konkretnego podmiotu do uczestniczenia $\mathrm{w}$ danym procesie, w określonym charakterze lub jako uprawnienie do występowania z skonkretyzowanym roszczeniem przeciwko innemu określonemu podmiotowi. ${ }^{18}$ Legitymacja procesowa jest immanentnie sprzężona ze stosunkiem prawnym, z którym związany jest spór, sam zaś stosunek wynika zasadniczo z prawa materialnego. W konsekwencji posiadanie legitymacji procesowej staje się udziałem stron będących zarazem podmiotami konkretnego stosunku prawnego, bowiem mają one interes prawny w określonym rozstrzygnięciu. ${ }^{19}$

Jednakże źródeł legitymacji procesowej upatrywać należy nie tylko w prawie podmiotowym. Jej podstawę stanowić mogą także przepis o charakterze procesowym. ${ }^{20} \mathrm{~W}$ ostatnim przypadku uznaje się, że legitymacja procesowa nie jest pochodną legitymacji materialnej (nie jest związana z prawem materialnym), ${ }^{21}$ lecz ma samoistną, odrębną podstawę prawną. Mowa tu o legitymacji procesowej podmiotów będących tzw. formalną stroną postępowania, do których obok prokuratora, rzeczników konsumentów, inspektów pracy zaliczyć należy także organizacje pozarządowe wytaczające powództwa na rzecz osób fizycznych. ${ }^{22}$ Wspólna cecha tych jakże specyficznych stron procesu wyraża się w tym, że rozstrzygnięcie wydane w sprawie, w której uczestniczą, nie będzie dotyczyć ich sfery prawnej, lecz ingero-

\footnotetext{
16 W. Broniewicz, Warunki uwzględnienia powództwa, „Państwo i Prawo” 2003, z. 3, s. 32 i powołana tam literatura; H. Pietrzkowski, Metodyka..., op. cit., s. 126; J. Jodłowski, Z. Resich, J. Lapierre, T. Misiuk-Jodłowska, K. Weitz, Postępowanie cywilne, Warszawa 2007, s. 448.

17 Ibidem.

18 W. Broniewicz, A. Marciniak, I. Kunicki, Postępowanie cywilne w zarysie, Warszawa 2014, s. 145; H. Pietrzkowski, Metodyka..., op. cit., s. 125; W. Siedlecki, Z. Świeboda, Postępowanie cywilne. Zarys wykładu, Warszawa 2003, s. 121.

19 Por. T. Wiśniewski, Przebieg procesu cywilnego, Warszawa 2013, s. 131.

20 J. Jodłowski, Z. Resich, J. Lapierre, T. Misiuk-Jodłowska, K. Weitz, Postępowanie..., op. cit., s. 211.

21 Ibidem.

22 K. Piasecki, Postępowanie..., op. cit., s. 237.
} 
wać będzie w interes prawny osób, na rzecz których występują. Z tego względu podmioty, których prawa mają podlegać ochronie w postępowaniu cywilnym określa się mianem „,rzeczywistej” strony procesu, choć faktycznie nie muszą one brać w nim udziału. ${ }^{23}$

Jako że organizacja występująca w postępowaniu w oparciu o przepisy art. 8 k.p.c. oraz art. 61 k.p.c. nie stanowi podmiotu spornego stosunku prawnego, kryteria oceny uprawniające ją do udziału w konkretnej sprawie mają odmienną podstawę prawną, zaś struktura elementów składających się na legitymację procesową organizacji pozarządowej stanowi zagadnienie dość złożone w swej istocie. Powodem powyższego stanu rzeczy wydaje się być specyficzny charakter przesłanek umożliwiających udział interesujących nas podmiotów w postępowaniu cywilnym. Na potrzeby niniejszego opracowania przesłanki te sklasyfikowano jako podmiotowe, $\mathrm{tj}$. związane z cechami leżącymi po stronie konkretnej organizacji oraz jako przedmiotowe, tj. dotyczące przedmiotu i celu postępowania.

W zasadzie jedynym czynnikiem przedmiotowym, który należy rozważyć w kontekście legitymacji procesowej, jest wskazana już w art. 8 k.p.c. potrzeba ochrony praw obywatela. Stanowi ona podstawową przesłankę przedmiotową uzasadniającą udział organizacji pozarządowej w postępowaniu cywilnym, będącą, jak się wydaje, sui generis interesem prawnym. Ocena, czy zachodzi potrzeba uczestniczenia $\mathrm{w}$ określonym postępowaniu cywilnym $\mathrm{z}$ uwagi na ochronę praw osoby fizycznej należy zawsze do konkretnej organizacji pozarządowej, zaś decyzja w tym przedmiocie pozostaje poza kompetencją sądu. ${ }^{24}$

Przechodząc natomiast do elementów o charakterze podmiotowym składających się na problematykę legitymacji procesowej organizacji pozarządowej w sprawach o ochronę środowiska nie można pominąć zagadnienia związanego z przedmiotem jej działania. Zgodnie z art. 61 k.p.c. kolejną przesłanką pozytywną umożliwiającą udział organizacji w postępowaniu cywilnym jest odpowiedni charakter działalności statutowej określony mianem ochrony środowiska. Ustawodawca nie precyzuje w k.p.c. znaczenia terminu „ochrona środowiska”, stąd zasadne wydaje się odwołanie do art. 3 pkt 13 ustawy z dnia 27 kwietnia 2001 r. Prawo ochrony środowiska. ${ }^{25}$ Zgodnie z jej treścią, przez ochronę środowiska rozumie się „(...) podjęcie lub zaniechanie działań, umożliwiające zachowanie lub przywracanie równowagi przyrodniczej; ochrona ta polega w szczególności na: a) racjonalnym kształtowaniu środowiska i gospodarowaniu zasobami środowiska zgodnie z zasadą zrównoważonego rozwoju, b) przeciwdziałaniu zanieczyszczeniom, c) przywracaniu elementów 
przyrodniczych do stanu właściwego (...)”. Chodzi tu zatem o całokształt działań lub na wybrane formy aktywności organizacji zmierzające do uchronienia tak środowiska przyrodniczego, jak i poszczególnych jego elementów przed niekorzystnym wpływem działalności człowieka i zachowanie jego naturalnego charakteru poprzez racjonalne, zharmonizowane, zgodne z prawem przyrody kształtowanie środowiska, życia człowieka i efektów jego działalności.

Odnotować wypada, iż statutowe działanie organizacji dotyczące ochrony środowiska musi pozostawać w bezpośrednim związku z przedmiotem sprawy. Wynika to wprost $\mathrm{z}$ art. $61 \S 1$ k.p.c., zgodnie z którym organizacje pozarządowe mogą wytaczać powództwa na rzecz obywateli w sprawach o ochronę środowiska, jeśli wchodzi to w zakres zadań statutowych organizacji. Zależność między zadaniami statutowymi organizacji a przedmiotem sprawy jest każdorazowo weryfikowana przez sąd, ${ }^{26}$ gdyż brak powyższego związku wydaje się przesądzać o nieposiadaniu legitymacji procesowej przez organizację. $Z$ powyższego względu podmioty te obowiązane są przedłożyć sądowi swój uwierzytelniony statut, w którym w sposób pozytywny bądź negatywny (poprzez zawarte w nim wyłączenia) określone są obszary aktywności takiej organizacji. ${ }^{27}$ Ponadto warto odnotować, iż w obszarze statutowych działań organizacji pozarządowej nie może się mieścić prowadzenie działalności gospodarczej, a zatem działania tego podmiotu nie mogą być ukierunkowane na osiąganie zysku.

Pamiętać jednak należy, iż idea ochrony środowiska jest tylko pośrednią przyczyną udziału organizacji pozarządowej w postępowaniu, gdyż przesłanką o charakterze zasadniczym jest ochrona praw obywatela. Organizacja pozarządowa nie może wytoczyć powództwa nie działając na rzecz osoby fizycznej i w jej interesie. Dopiero połączenie obydwu wartości (potrzeby ochrony praw obywatela i środowiska) kształtuje legitymację procesową do udziału w postępowaniu (np. wytoczenie na rzecz osoby fizycznej odszkodowania i zadośćuczynienia w związku ze szkodą wywołaną zatruciem ujęcia wody pitnej wskutek działalności zakładu przemysłowego). Podkreślić należy, iż analizując charakter działalności organizacji bez wątpienia możemy tu mówić o elementach składających się na pojęcie legitymacji procesowej formalnej, nie zaś na zagadnienie zdolności sądowej i procesowej. Ostatnie ze wspomnianych atrybutów przysługują organizacjom pozarządowym bez względu na rodzaj działalności. Jeśli bowiem organizacja jest jednym z podmiotów wskazanych w art. 64 § 2 i 65 § 1 k.p.c., może ona występować we własnym interesie, w charakterze strony w każdej sprawie, choćby jej działania polegały na prowadzeniu działalności gospodarczej lub związane były z obszarami niewskazanymi w art. 61 k.p.c.

Por. P. Grzegorczyk, (w:) T. Ereciński (red.), Kodeks postępowania cywilnego. Komentarz. Postępowanie rozpoznawcze. Tom I, Warszawa 2012, s. 306; F. Zedler, Recenzja książki: T. Misiuk, Udział organizacji społecznych w ochronie praw obywateli w sądowym postępowaniu cywilnym, Warszawa 1972, s. 298.
} 
Na końcu warto także wspomnieć o szczególnym uprawnieniu organizacji pozarządowych, zwanych ekologicznymi, które na podstawie art. 80 oraz 328 ustawy Prawo o ochronie środowiska uprawnione są do występowania $\mathrm{z}$ roszczeniem o zaprzestanie reklamy lub innego rodzaju promocji towaru lub usługi, jeśli reklama ta lub inny rodzaj promocji zawiera treści propagujące model konsumpcji sprzeczny z zasadami ochrony środowiska i zrównoważonego rozwoju, a w szczególności wykorzystuje obraz dzikiej przyrody do promowania produktów i usług negatywnie wpływających na środowisko przyrodnicze. W opisywanym przypadku organizacjom ekologicznym przyznano szczególną legitymację procesową do występowania w interesie publicznym, stąd do procesów wszczynanych na podstawie art. 80 i 328 wskazanej ustawy nie mają zastosowania normy art. 61 k.p.c.

Ostatnią, równie istotną kwestię, która winna zostać poddana analizie, stanowi pisemna zgoda osoby fizycznej na udział organizacji pozarządowej w postępowaniu, przy czym odnotować należy, iż obowiązek przedstawienia sądowi wspomnianej zgody dotyczy zarówno wytoczenia przez organizację powództwa (art. $61 \S 1$ k.p.c.), jak i przystąpienia do strony w toku toczącego się postępowania (art. $61 \S 2$ k.p.c.). Zgodę tę postrzegać należy tak w aspekcie podmiotowym, jak i przedmiotowym, bowiem osoba fizyczna wyraża zgodę na udział konkretnej organizacji w określonym - pod względem przedmiotowym - postępowaniu. Podkreślić należy, że charakter prawny interesującej nas zgody stanowi przedmiot doktrynalnych kontrowersji. Część przedstawicieli doktryny opowiada się za materialną naturą zgody, co automatycznie czyni ją elementem składowym legitymacji procesowej. ${ }^{28}$ Jednakże na gruncie literatury przedmiotu dostrzegalny jest również pogląd, stosownie do którego zgoda osoby fizycznej na udział organizacji pozarządowej w postępowaniu ma charakter formalny i niedołączenie do pozwu dokumentu będącego wyrazem takiej zgody należy traktować jako brak formalny pozwu, podlegający uzupełnieniu w trybie art. 130 k.p.c., pod rygorem zwrotu pisma. ${ }^{29}$ Ostatnie z zapatrywań wydaje się jednak nie mieć podstaw prawnych. Jak słusznie podkreślono w orzecznictwie, ${ }^{30}$ bez zgody osoby fizycznej organizacja pozarządowa nigdy nie będzie mogła wszcząć postępowania z pozytywnym skutkiem, polegającym na uwzględnieniu powództwa. Kwestia nieuzyskania wymaganej zgody zasadniczo nie wykazuje związku z problematyką braków formalnych pozwu. Zgoda rzeczywistej strony procesu stanowi materialny substrat legitymacji procesowej organizacji pozarządowych i w tym kierunku dokonano nowelizacji przepisów k.p.c., nakładając na organizacje obowiązek posiadania zgody w każdej sprawie z udziałem rzeczonych podmiotów, jeśli działają w postępowaniu na rzecz osób fizycznych. Możliwość wytaczania powództwa lub

28 Por. P. Grzegorczyk, (w:) T. Ereciński (red.), Kodeks..., op. cit., s. 305. P. Telenga, (w:) A. Jakubecki, Komentarz..., op. cit., LEX nr 166020. 
przystępowania do procesu bez zgody osoby, której interesów owo postępowanie bezpośrednio dotyczy, zanadto ingerowałoby w zasadę dyspozycyjności związanej z rozporządzaniem prawami o charakterze podmiotowym, stanowiącymi przedmiot procesu. Tezę tę potwierdza treść uzasadnienia projektu ustawy nowelizującej k.p.c. w 2011 r. ${ }^{31}$ (druk sejmowy nr 4332), stosownie do którego: , (...) dla uzyskania przez organizacje legitymacji procesowej $w$ celu wytoczenia powództwa na rzecz osoby fizycznej, niezbędne będzie uprzednie udzielenie przez tę osobę pisemnej zgody na występowanie organizacji na jej rzecz w konkretnej sprawie". ${ }^{32}$

Jak wspomniano na wstępie, nie budzi wątpliwości teza, iż brak legitymacji procesowej strony wywołuje skutek prawny w postaci oddalenia powództwa. Wyrok oddalający powództwo zapada wtedy, gdy sąd stwierdza nieistnienie podstaw materialnoprawnych uzasadniających wystąpienie przez dany podmiot z wynikającym ze stosunku prawnego konkretnym roszczeniem przeciwko drugiemu, określonemu podmiotowi. Jednakże gdy legitymacja procesowa ma wyłącznie charakter formalny i nie wynika z przepisów materialnoprawnych, brak jest jednomyślności wśród przedstawicieli doktryny w kwestii obowiązku oddalenia powództwa z powodu braku legitymacji procesowej. Wprawdzie problematyka braku rzeczonej legitymacji przez podmioty będące tzw. formalnymi stronami procesu jest podejmowana dość rzadko przez przedstawicieli doktryny, niemniej warto wspomnieć, że istnieje koncepcja, zgodnie z którą okoliczność nieposiadania legitymacji przez tak specyficzne strony procesu jako prokurator lub organizacja pozarządowa winna skutkować - nie oddaleniem powództwa, lecz odrzuceniem pozwu. ${ }^{33}$ Argument potwierdzający słuszność powyższego poglądu opiera się - w opinii jego zwolenników - na zasługującym na aprobatę podziale źródeł legitymacji procesowej na legitymację materialną (wynikającej z prawa podmiotowego lub interesu prawnego) i formalną (wynikającą z ustawy). Legitymacja materialna stanowi przesłankę materialną powództwa, jej brak - uzasadnia odmowę udzielenia ochrony prawnej. Konsekwencją powyższych ustaleń jest fakt, że jeśli legitymacja procesowa nie wynika z legitymacji materialnej, a zatem ma charakter jedynie formalny, zaś materialna służy innej osobie (stronie rzeczywistej), brak legitymacji formalnej nie może stanowić materialnej przesłanki do oddalenia powództwa. Jest to niedopuszczalne, bowiem w konkretnej sprawie istnieje przecież osoba posiadająca legitymację materialną i sam fakt wystąpienia z powództwem na rzecz tej osoby przez nieuprawnioną organizacją pozarządową nie uzasadnia oddalenia powództwa. W opisywanej sytuacji sąd w ogóle nie może rozpoznawać spornego stosunku prawnego, w konsekwencji więc zachodzi brak jakichkolwiek podstaw do wydania wyroku. Wprawdzie przed-

31 Druk sejmowy VI kadencji, nr 4332, pkt IV. Treść aktu dostępna jest na stronie www.orka.sejm.gov.pl

32 Ibidem, s. 19.

33 Tak: J. Jodłowski, Z. Resich, J. Lapierre, T. Misiuk-Jodłowska, K. Weitz, Postępowanie..., op. cit., s. 213; T. Misiuk, Udział organizacji społecznych w ochronie praw obywateli w sądowym postępowaniu cywilnym, Warszawa 1972, s. $161 \mathrm{i} \mathrm{n}$. 
stawiciele doktryny, którzy sformułowali powoływaną teorię przyznają, że przepisy k.p.c. regulujące przyczyny odrzucenia pozwu nie wymieniają okoliczności braku legitymacji procesowej, niemniej stwierdzając, iż jest to zapewne luka w prawie, autorzy ci podtrzymują swoje stanowisko, stosownie do którego po zastosowaniu analogii, w opisywanym przypadku uzasadnione jest odrzucenie pozwu. ${ }^{34}$

Powyższe zapatrywanie należy uznać za budzące wątpliwości z następujących względów: wprawdzie uprawnienie organizacji pozarządowej i innych podmiotów tego rodzaju do udziału w procesie w charakterze strony nie wynika $\mathrm{z}$ prawa podmiotowego, lecz z przepisu ustawy, wydaje się jednak, iż wspomniani autorzy w zbyt formalny sposób postrzegają istotę legitymacji procesowej podmiotów niebędących rzeczywistymi stronami procesu. Organizacje pozarządowe mają wszak sui generis interes prawny w wytoczeniu powództwa (ochrona praw obywatel). Owszem, brak legitymacji procesowej np. z powodu nieuzyskania zgody osoby fizycznej, na rzecz której organizacja wytoczyła powództwo lub z uwagi na nieistnienie powiązań między statutową działalnością organizacji a przedmiotem procesu różni się w swej specyfice od sytuacji, w której osoba, w stosunku do której brak jest materialnoprawnych podstaw do wytoczenia powództwa, czyni to. Jednakże zarówno w jednym, jak i w drugim przypadku skutek jest identyczny: pozew wniosła osoba nieuprawniona, tj. osoba, której nie przysługuje roszczenie skonkretyzowane w pozwie. Argument sformułowany przez cytowanych autorów, stosownie do którego niezasadne jest oddalenie powództwa takich podmiotów, jak organizacja pozarządowa $\mathrm{z}$ tego względu, że istnieje osoba, która posiada legitymację materialną, jest chybiony, ponieważ podawałby w wątpliwość słuszność oddalenia powództwa również w przypadku innych podmiotów nieposiadających legitymacji materialnej i niebędących zarazem organizacją pozarządową lub prokuratorem itp. Podkreślić należy, że wyrok oddalający powództwo z powodu braku legitymacji procesowej przez organizację pozarządową nie wywołuje takiego skutku, że rzeczywista strona procesu nie będzie mogła wytoczyć powództwa w tej samej sprawie z uwagi na istnienie prawomocnego wyroku (art. 199 pkt 2 k.p.c.). Oddalenie powództwa z powodu braku legitymacji procesowej oznacza jedynie, iż sąd odmówił udzielenia ochrony prawnej osobie na rzecz, której wystąpił podmiot nieuprawniony, tj. nieposiadający należytej legitymacji procesowej do wszczęcia postępowania.

\section{Podsumowanie}

Udział organizacji pozarządowej zajmującej się ochroną środowiska w postępowaniu cywilnym - jak starano się wykazać w niniejszym opracowaniu - uwarunkowany jest zaistnieniem szeregu przesłanek związanych bezpośrednio z samą organizacją. Brak którejkolwiek $\mathrm{z}$ przesłanek stanowiących przedmiot analizy

Tak: J. Jodłowski, Z. Resich, J. Lapierre, T. Misiuk-Jodłowska, K. Weitz, Postępowanie..., op. cit., s. 213. 
- w zależności od ich charakteru - implikuje odmienne konsekwencje prawne. Do przesłanek o charakterze formalnym zaliczyć należy zdolność sądową oraz zdolność procesową - atrybuty, bez których żaden z podmiotów nie może wszcząć procesu, ani w nim uczestniczyć, pod rygorem odrzucenia pozwu, zawieszenia i umorzenia postępowania lub nieważności postępowania. Przeciwstawić im należy legitymację procesową - przesłankę o charakterze materialnym, której nieziszczenie, wbrew zapatrywaniom niektórych przedstawicieli doktryny, skutkuje wydaniem wyroku oddalającego powództwo, będącego naturalnym następstwem braku zgody sądu na występowanie z konkretnym roszczeniem przez podmiot do tego nieuprawniony. W niniejszym artykule sformułowano tezę, iż istota legitymacji procesowej organizacji pozarządowej wyraża się między innymi w sui generis interesie prawnym organizacji, będącej w gruncie rzeczy interesem osoby fizycznej, na rzecz której organizacja występuje w postaci ochrony praw obywatela. Ponadto działalność organizacji zajmującej się ochroną środowiska winna korespondować z przedmiotem procesu, a także organizacja taka musi uzyskać pisemną zgodę osoby fizycznej na wytoczenie powództwa na jego rzecz. 


\section{PREREQUISITES OF PARTICIPATION OF NON-GOVERNMENTAL ORGANIZATIONS IN CIVIL PROCEEDINGS WITH SPECIAL REFERENCE TO ORGANIZATIONS INVOLVED IN PROTECTION OF THE NATURAL ENVIRONMENT}

Non-governmental organizations, which according to their statute do not conduct business activities but are involved in protection of the natural environment, may initiate civil proceedings or join with a party during any stage of a case. The aim behind participation of non-governmental organizations is to protect a third-person's rights. This is how a natural person might be able to get help in claiming their rights if such rights are breached due to activities which pose a threat to the environment.

The article presents the issue of substantive prerequisites (right of action) and formal prerequisites (capacity to be party in civil proceedings and capacity to undertake procedural actions) of non-governmental organizations, with special reference to organizations involved in the protection of the natural environment. The author describes the problems associated with right to action faced by a nongovernmental organization when acting not in its own interest, but in the interest of someone else.

Keywords: non-governmental organization, prerequisites, right of action, capacity to be a party of in civil proceedings 